\title{
KUALITAS AIR SUNGAI DI KAWASAN WISATA PANTAI PETITENGET, KEROBOKAN KABUPATEN BADUNG BALI
}

\author{
Budiarsa Suyasa W *), Sri Kunti Pancadewi G. A, Iryanti E. Suprihatin, Dwi Adi \\ Suastuti G. A. \\ Laboratorium Kimia Lingkungan, Jurusan Kimia FMIPA ,UniversitasUdayana \\ *Email:budiarsa_suyasa@unud.ac.id
}

\begin{abstract}
ABTRACT
In order to maintain the environmental carrying capacity of coastal tourism, this research was conducted to determine the condition of water pollution of river in the Petitenget beach area and pollutant source activities. Determination of water quality is carried out by analyzing the water sample taken at several sampling points in the four rivers that lead to the Petitenget beach. Determined the pollution index value of the physical chemical and biological pollution parameters. The results showed that the four rivers that flow into the Petitenget Beach area had been contaminated with indications of $\mathrm{pH}, \mathrm{BOD}, \mathrm{COD}$, ammonia, Coliform and E. coli which exceeded water quality category III class quality (PerGub Bali No 16 Year 2016). The four rivers are included in the criteria of severe contamination. The four rivers have experienced physical damage or structural changes that have very high discharge fluctuations both in quantity and quality. Slimy basic structure, smelly and slum aesthetic waters. While the indication of the impact of pollution is waste water which is directly discharged into the river from hotels, restaurants, homestays, commercial centers and settlements.
\end{abstract}

Keywords: river, pollution index, criteria, indications and wastewater

\section{PENDAHULUAN}

Kawasan Kuta utara dan Kerobokan yang menjadi hulu dari sungai yang bermuara di Pantai Petitenget berkembang pesat akomodasi wisata yang memenuhi sebagian besar ruang tangkapan air sungai tersebut. Dengan penerapan upaya pengelolaan limbah yang tidak layak dari pengusaha dan masyarakat secara luas maka loloan menjadi tempat pembuangan air limbah. Karakteristik limbah yang mengancam loloan tersebut adalah dari akomodasi wisata dan rumah tangga, terindikasi limbah tersbut berupa limbah rumah makan, kamar mandi/WC, pencucian dan laundry. Air limbah ini yang memberi andil bagi kondisi loloan secara fisik tampak dari warna kekeruhan dan bau yang memberi kesan estetika buruk. Secara kimia dan biologis dapat muncul ancaman pencemaran, ganguan ekologis dan kesehatan.

Kondisi tersebut menimbulkan dampak yang tidak baik terutama di muara sungai/loloan. Timbulan bau, kotor dan estetika lingkungan yang tidak baik dapat mengancam keberlangsungan kegiatan pariwisata karena lokasi tersebut sangat berdekatan dengan kawasan pantai. Menurunnya kualitas lingkungan pada umumnya di sebabkan oleh kuantitas dan kualitas limbah yang dibuang ke media lingkungan, sehingga terakumulasi di wilayah muara sungai/loloan disebabkan oleh kemampuan daya dukung dan daya tampung lingkungan yang sudah tidak memadai akibat aktivitas manusia dan 
usaha/kegiatan. Oleh karena itu, untuk mengantisipasi tercemarnya muara sungai/loloan serta menyiapkan data penunjang dalam menyusun kebijakan dan perencanaan lebih untuk mengatasi pencemaran dan kerusakan air muara/loloam, maka perlu dilakukan identifikasi parameter air muara sungai/loloan. Untuk dapat mengidentifikasi parameterpencemar air muara sungai/loloan, diperlukan adanya Identifikasi Parameter Kerusakan Kualitas Air Muara Sungai/Loloan. Buruknya kualitas air sungai yang bermuara di loloan Petitenget Badung memderi tekanan dan berdampak pada penurunan kualitas air laut di pantai Kuta. yang akan berdampak ekologis dan ekonomis. Mengingat dampak air sungai terhadap kualitas air laut mendorong penelitian untuk meneliti kualitas air sungai di loloan Petitenget yang dipengaruhi oleh limbah domestic dan aktivitas pariwisata seperti buangan limbah hotel.

Tujuan dari penelitian ini adalah untuk mengetahui mutu parameterparameter pencemar air muara sungai / loloan sehingga dapat dilakukan mencegahan, pemantauan dan penanggulangan pencemaran dan kerusakan air pada muara sungai/loloan, melalui kegiatan lebih lanjut. (BOD,COD, TSS, TDS, Amonia, Nitrat, Fosfat, $\mathrm{pH}$, fecal Coli dan Coliform)

\section{METODOLOGI}

Penelitian dilakukan untuk menentukan tingkat pencemaran air sungai (loloan) di kawasan pantai Petitenget. Sumber pencemar teridentifikasi didaerah tersebut meliputi hotel, restoran, kegiatan/usaha jasa, niaga, dan pemukiman.Penentuan kualitas air yang diambil di beberapa titik sampling disetiap sungai(4 sungai) yang bermuara di pantai Petitenget ditentukan nilai indeks pencemaran (IP) dari nilai parameter pencemaran fisik kimia dan biologi di Laboratorium. Uji parameter fisik terdiri dari suhu, warna, bau. Uji parameter organik terdiri dari BOD, COD, Amonia $\left(\mathrm{NH}_{3}\right)$, Fosfat $\left(\mathrm{PO}_{4}\right)$, TSS, TDS, pH dan Uji parameter mikrobiologi terdiri dari E. coli dan total colliform. Lokasi penelitian (tempat pengambilan sampel) air sungai adalah di empat sungai kecil yang bermuara sepanjang pantai Petitenget. Penelitian dilakukan pada bulan Mei 2018 sampai dengan bulan Juli 2018. Lokasi pengambilan sampel disajikan pada Gambar 1.

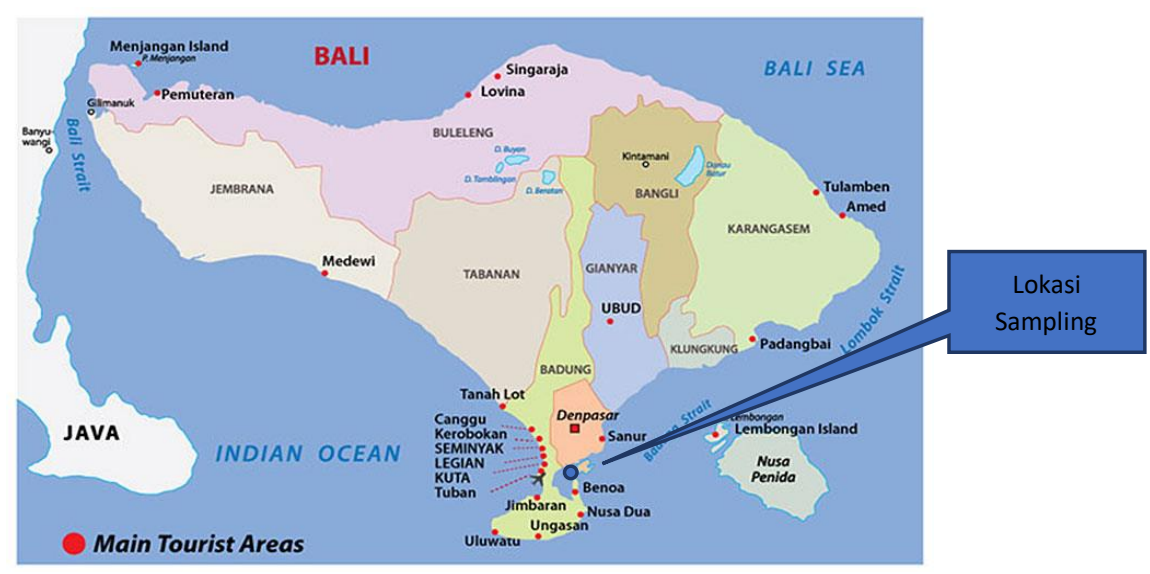

Gambar 1.

Lokasi Pengambilan Sampel di Kawasan Wisata Petitenget(tanda biru) 
Metode penentuan stasiun sampel air dilakukan dengan cara purposive sampling yaitu penentuan stasiun pengamatan dilakukan dengan mempertimbangkan pendekatan representatif tempat dan waktu dan kondisi lokasi penelitian, seperti wilayah di sekitar titik sampel sebagai sumber dampak serta aktivitas yang ada di lokasi (sungai) tersebut.Teknik pengambilan sampel air untuk pengukuran parameter fisik, kimia dan mikrobiologi pada masing-masing titik sampel (TS) dengan cara menentukan area sampling, kemudian mengambil sampel air di $2-3$ titik dengan $1 / 2$ kedalaman sungai pada satu lokai sampling. Pengambilan sampel air memperhatikan juga sebaran horisontal dan vertikal area sampling. Sampel air yang diambil kemudian dicampur sehingga menjadi komposit sampel. Pada setiap sungai (loloan) diteentukan titik pengambilan sampel tergantung panjang sungai dan kondisi lokasi sungai tempat pengambilan sampel. Pada sekali tahap pengambilan sampel dilakukan pengambilan sampel air sekaligus disemua titik dimulai pagi hingga selesai, pada pengulangan kedua dan ketiga dilakukan pergantian start waktu pengambilan sampel air.

\section{HASIL DAN PEMBAHASAN}

\subsection{Loloan Sisi Utara Pura Petitenget Kerobokan Badung (Loloan 1)}

A. Kualitas dan Status Mutu Air Loloan sisi utara Pura Petitenget

Loloan ini berupa sungai kecil yang awalnya merupakan saluran irigasi, namun sekarang menjadi tempat pengaliran limbah dari berbagai aktivitas domestic. Padatnya pembangunan terutama akomodasi wisata disepanjang sungai memberi pengaruh pada kondisi fisik dan kualitas pencemaran air sungai yang bermuara di Pantai Petitenget tersebut. Berikut ditunjukan hasil pemeriksaan dan analisis sampel air di titik pengambilan sampel di lokasi tersebut.

Tabel 1. Hasil Pengukuran kualitas sampel air Loloan Sisi Utara Pura Petitenget Bulan April-Juni 2018

\begin{tabular}{llrrrrr}
\hline Parameter & Satuan & \multicolumn{1}{l}{ L11* } & L12* & L13* & Rerata & BM III \\
\hline Suhu & ${ }^{\circ} \mathrm{C}$ & 28.0 & 28.5 & 28.4 & 28.3 & 28.5 \\
TDS & $\mathrm{mg} / \mathrm{L}$ & 2169.3 & 891.3 & 758.1 & 1272.9 & 1000 \\
TSS & $\mathrm{mg} / \mathrm{L}$ & 9.3 & 11.2 & 21.6 & 14.0 & 400 \\
pH & - & 5.2 & 4.0 & 3.7 & 4.3 & 6 \\
BOD & $\mathrm{mg} / \mathrm{L}$ & 22.6 & 28.2 & 36.8 & 29.2 & 6 \\
COD & $\mathrm{mg} / \mathrm{L}$ & 60.5 & 63.1 & 136.5 & 86.7 & 50 \\
Total P & $\mathrm{mg} / \mathrm{L}$ & 0.4 & 1.2 & 0.6 & 0.7 & 1 \\
NH3 & $\mathrm{mg} / \mathrm{L}$ & 0.0 & 0.1 & 0.1 & 0.1 & 0 \\
fecal & $\mathrm{Jml} / 100 \mathrm{ml}$ & 53370.0 & 53767.5 & 53866.9 & 53668.1 & 2000 \\
Coliform & $\mathrm{Jml} / 100 \mathrm{ml}$ & 11433.3 & 14608.3 & 16152.1 & 14064.6 & 10000 \\
\hline
\end{tabular}

Keterangan:

L11,L12,L13 = berturut-turut lokasi titik sampling dari hilir ke hulu loloan sisi utara Pura Petitenget *) = nilai rerata bulan April, Mei dan Juni

BM III = Baku Mutu air golongan III PerGub Bali No 16 Tahun 2016 


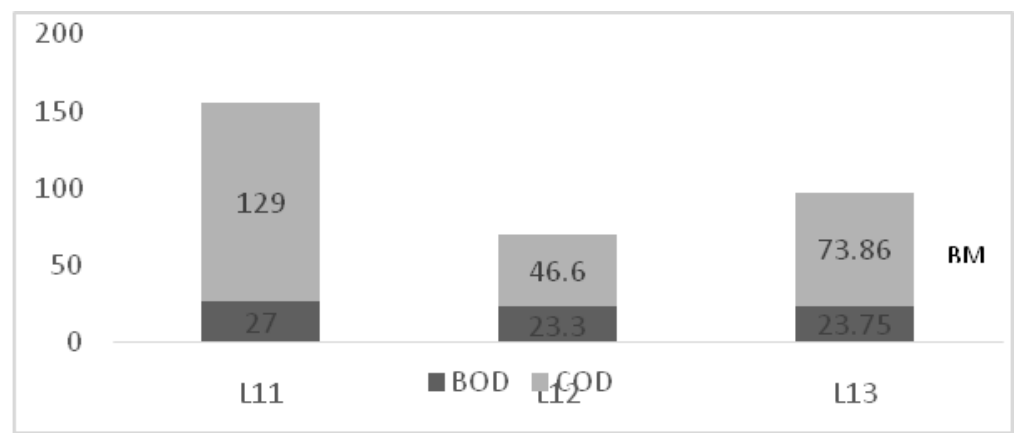

Gambar 2.

Karakter Beban oksidasi (BOD dan COD) Loloan Sisi Utara Pura Petitenget Kerobokan Badung.

Keterangan

L11,L12,L13 = berturut-turut lokasi titik sampling dari hilir ke hulu loloan sisi utara Pura Petitenget BM III = Baku Mutu air golongan III PerGub Bali No 16 Tahun 2016

Tabel 2. Profil kualitas sampel air Loloan Sisi Utara Pura Petitenget Bulan April Juni 2018

\begin{tabular}{lcrrrrr}
\hline Parameter & Satuan & \multicolumn{1}{c}{ L11 } & \multicolumn{1}{c}{ L12 } & L13 & \multicolumn{1}{c}{ rerata } & BM III \\
\hline suhu & ${ }^{\circ} \mathbf{C}$ & 28.0 & 28.5 & 28.4 & 28.3 & 28.5 \\
TDS & $\mathbf{m g} / \mathbf{L}$ & 2169.3 & 891.3 & 758.1 & 1272.9 & 1000 \\
TSS & $\mathbf{m g} / \mathbf{L}$ & 9.3 & 11.2 & 21.6 & 14.0 & 400 \\
pH & - & 5.2 & 4.0 & 3.7 & 4.3 & 6 \\
BOD & $\mathbf{m g} / \mathbf{L}$ & 22.6 & 28.2 & 36.8 & 29.2 & 6 \\
COD & $\mathbf{m g} / \mathbf{L}$ & 60.5 & 63.1 & 136.5 & 86.7 & 50 \\
Total P & $\mathbf{m g} / \mathbf{L}$ & 0.4 & 1.2 & 0.6 & 0.7 & 1 \\
NH3 & $\mathbf{m g} / \mathbf{L}$ & 0.0 & 0.1 & 0.1 & 0.1 & 0 \\
fecal & $\mathbf{J m l} / \mathbf{1 0 0}$ & 53370.0 & 53767.5 & 53866.9 & 53668.1 & 2000 \\
coliform & $\mathbf{J m l} / \mathbf{1 0 0} \mathbf{m l}$ & 11433.3 & 14608.3 & 16152.1 & 14064.6 & 10000 \\
\hline
\end{tabular}

L11,L12,L13 = berturut-turut lokasi titik sampling dari hilir ke hulu loloan sisi utara Pura Petitenget *) = nilai rerata bulan April, Mei dan Juni

BM III = Baku Mutu air golongan III PerGub Bali No 16 Tahun 2016

$\square \square \square=$ Warna hijau (<BM III), warna Kuning(mendekati BM III), warna merah(>BM III)

Pada Tabel 2dapat dilihat bahwa terdapat beberapa parameter pencemar yang melampaui batas Baku Mutu Air Golongan III yang dipersyaratkan dalam PerGub Bali No.16 Tahun 2016. Parameter pencemar yang melebihi baku mutu salah satunya adalah Total Dissolved Solid (TDS) yang merupakan salah satu parameter yang mengindikasikan terdapat padatan terlarut (seperti kalsium, magnesium, potassium, natrium, bikarbonat, klorida dan sulfat) dalam jumlah yang besar di titik sampling L11 yang terletak di hilir loloan. Tingginya konsentrasi TDS pada sampel air loloan di hilir dapat disebabkan oleh adanya pembuangan air limbah baik domestik maupun industri ke dalam loloan. Bahan kimia yang digunakan untuk pemrosesan bahan mentah oleh industri merupakan salah satu sumber pencemar yang menyumbang konsentrasi TDS terbesar.

Parameter lainnya yang berpotensi memunculkan masalah pencemaran yang lebih besar adalah $\mathrm{pH}, \mathrm{BOD}, \mathrm{COD}$, fecal dan coliform yang memiliki konsentrasi diatas baku mutu. Tingginya BOD dan 
COD mengindikasikan tingginya zat organik yang terlarut dalam air loloan baik biodegradable maupun nonbiodegradable. Tingginya zat organic dalam air loloan dapat menjadi masalah serius karena semakin tinggi zat organic maka semakin banyak mikroorganisme yang akan tumbuh dan berkembang biak yang menjadikan zat organic sebagai sumber makanan. Zat organic juga dapat menyebabkan pencemaran yang berkelanjutan karena kemampuan terdispersi dan terakumulasi yang cepat.

Sementara parameter fecal dan coliform menunjukan jumlah bakteri yang teridentifikasi pada air loloan. Fecal merupakan parameter jumlah bakteri pathogen yang dapat menimbulkan penyakit dan coliform merupakan parameter jumlah bakteri yang berpotensi menjadi agen pembawa penyakit.

B. Status Kualitas Air Loloan sisi utara Pura Petitenget

Tabel 3. Penentuan status/kriteria kualitas air loloan sisi utara Pura Petitenget Kerobokan Badung.

\begin{tabular}{lllllll}
\hline & No & Parameter & Satuan & BM III & \multicolumn{2}{c}{ Hasil Perhitungan } \\
& & & \multicolumn{2}{c}{ Maksimum } & Minimum & Rerata \\
\hline A & Fisika & & & 0 & 0 \\
1 & Suhu & oC & 28.5 & 0 & 0 & -3 \\
2 & TDS & mg/L & 1000 & -1 & 0 & 0 \\
3 & TSS & mg/L & 400 & 0 & 0 & \\
B & Kimia & & & & & -6 \\
1 & pH & & & -2 & -2 & -6 \\
2 & NH3-N & mg/L & 0 & -2 & -2 & 0 \\
3 & Phospat & mg/L & 1 & 0 & 0 & -6 \\
4 & BOD & mg/L & 6 & -2 & -2 & -6 \\
5 & COD & mg/L & 50 & -2 & 0 & -9 \\
C & Biologi & & & & -3 & -9 \\
1 & Fecal coli & jml/100m & 2000 & -3 & -3 & -45 \\
2 & Total Coli & jml/100m & 10000 & -3 & -12 & \\
\hline
\end{tabular}

Kelas D, tercemar berat( $>-31)$

BM III = Baku Mutu air golongan III PerGub Bali No 16 Tahun 2016

\subsection{Loloan Sisi Selatan Pura Petitenget Kerobokan Badung (Loloan 2)}

A. Kualitas dan Status Mutu Air Loloan sisi Selatan Pura Petitenget

Pada loloan ini ditentukan 6 titik pengambilan sampel yang disesuiakan dengan kondisi dan panjang sungai dilokasi penelitian. Loloan ini berupa sungai sedang yang sebagian besar terbuka dengan penataan secara privasi sesuai dengan lokasi untuk menambah estetika. namun seperti pada umumnya dilokasi padat, menjadi tempat pengaliran limbah dari berbagai aktivitas domestic. Padatnya pembangunan terutama akomodasi wisata disepanjang sungai memberi pengaruh pada kondisi fisik dan kualitas pencemaran air sungai yang bermuara di Pantai Petitenget tersebut. Berikut ditunjukan hasil pemeriksaan dan analisis sampel air di titik pengambilan sampel di lokasi tersebut. 
Tabel 4. Hasil Pengukuran kualitas sampel air Loloan Sisi Selatan Pura Petitenget Bulan April - Juni 2018

\begin{tabular}{|l|l|r|r|r|r|r|r|r|r|}
\hline \multicolumn{1}{|c|}{ Parameter } & \multicolumn{1}{c|}{ Satuan } & L21* & L22* & L23* & L24* & L25* & L26* & rerata & BMIII \\
\hline Suhu & ${ }^{\circ} \mathrm{C}$ & 28.5 & 27 & 28 & 28 & 27.5 & 28.00 & 27.8 & 28.5 \\
\hline TDS & $\mathrm{mg} / \mathrm{L}$ & 1528 & 521 & 462.5 & 505 & 420 & 152.00 & 598.1 & 1000 \\
\hline TSS & $\mathrm{mg} / \mathrm{L}$ & 17 & 8 & 4 & 4.5 & 5 & 36.00 & 12.4 & 400 \\
\hline $\mathrm{pH}$ & - & 3.75 & 3.75 & 3.86 & 3.9 & 3.9 & 3.89 & 3.8 & 6 \\
\hline $\mathrm{BOD}$ & $\mathrm{mg} / \mathrm{L}$ & 13.4 & 12.3 & 17 & 10.4 & 16.3 & 21.75 & 15.2 & 6 \\
\hline $\mathrm{COD}$ & $\mathrm{mg} / \mathrm{L}$ & 97.84 & 77.18 & 63.02 & 29.16 & 155.1 & 107.60 & 88.3 & 50 \\
\hline Total Fosfat & $\mathrm{mg} / \mathrm{L}$ & 0.32 & 0.06 & 0.074 & 0.49 & 0.21 & 0.32 & 0.2 & 1 \\
\hline NH3 & $\mathrm{mg} / \mathrm{L}$ & 0.035 & 0.05 & 0.03 & 0.03 & 0.03 & 0.27 & 0.1 & 0 \\
\hline Fecal Coliform & $\mathrm{Jml} / 100 \mathrm{ml}$ & 90000 & 90000 & 35000 & 28000 & 270 & 28000 & 45211.7 & 2000 \\
\hline Total Coliform & $\mathrm{Jml} / 100 \mathrm{ml}$ & 14000 & 22000 & 12000 & 3300 & 1500 & 10000 & 10466.7 & 10000 \\
\hline
\end{tabular}

Keterangan : L11,L12,L13 = berturut-turut lokasi titik sampling dari hilir ke hulu loloan sisi Selatan Pura Petitenget

*) = nilai rerata bulan April, Mei dan Juni

BM III = Baku Mutu air golongan III PerGub Bali No 16 Tahun 2016

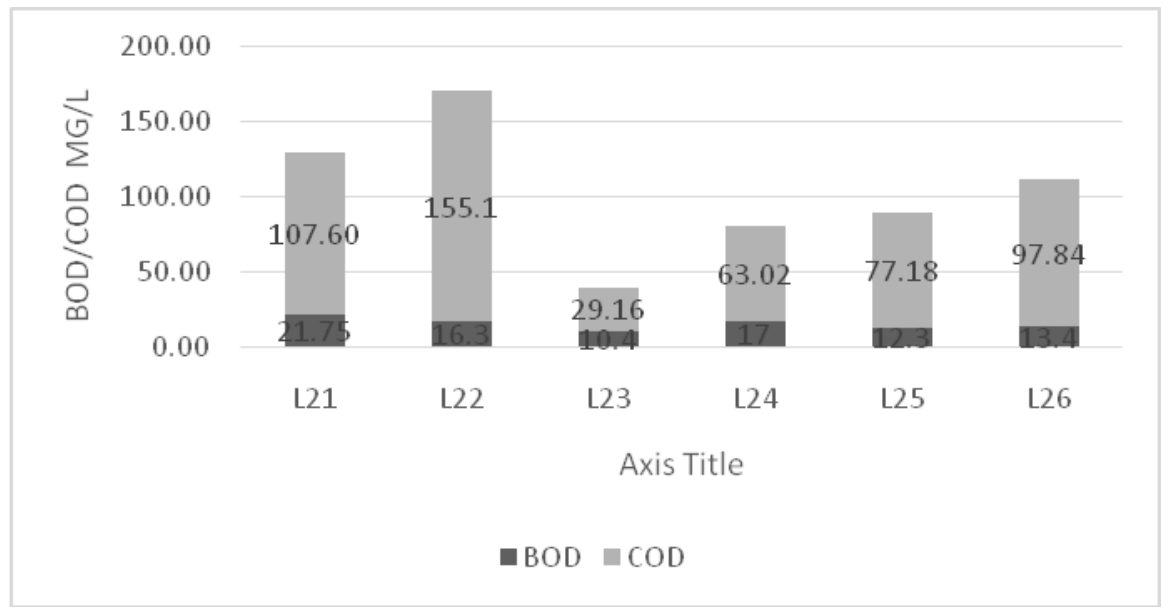

Gambar 2.

Karakter Beban oksidasi (BOD dan COD) Loloan Sisi Selatan Pura Petitenget Kerobokan Badung.

Keterangan:

L11,L12,L13 = berturut-turut lokasi titik sampling dari hilir ke hulu loloan sisi Selatan Pura Petitenget BM III = Baku Mutu air golongan III PerGub Bali No 16 Tahun 2016

Tabel 5. Profil kualitas sampel air Loloan Sisi Selatan Pura Petitenget Bulan April - Juni 2018

\begin{tabular}{llrrrrrrrr}
\hline \multicolumn{1}{c}{ Parameter } & \multicolumn{1}{c}{ Satuan } & \multicolumn{1}{c}{ L21 } & L22 & L23 & L24 & L25 & \multicolumn{1}{c}{ L26 } & rerata & BMIII \\
\hline Temperatur & ${ }^{\circ} \mathrm{C}$ & 28.5 & 27 & 28 & 28 & 27.5 & 28.00 & 27.8 & 28.5 \\
Residu & & & & & & & & & \\
Terlarut & $\mathrm{mg} / \mathrm{L}$ & 1528 & 521 & 462.5 & 505 & 420 & 152.00 & 598.1 & 1000 \\
$\mathrm{TSS}$ & $\mathrm{mg} / \mathrm{L}$ & 17 & 8 & 4 & 4.5 & 5 & 36.00 & 12.4 & 400 \\
$\mathrm{pH}$ & - & 3.75 & 3.75 & 3.86 & 3.9 & 3.9 & 3.89 & 3.8 & 6 \\
BOD & $\mathrm{mg} / \mathrm{L}$ & 13.4 & 12.3 & 17 & 10.4 & 16.3 & 21.75 & 15.2 & 6
\end{tabular}




\begin{tabular}{|c|c|c|c|c|c|c|c|c|c|}
\hline Parameter & Satuan & L21 & L22 & L23 & L24 & L25 & L26 & rerata & BMIII \\
\hline COD & $\mathrm{mg} / \mathrm{L}$ & 97.84 & 77.18 & 63.02 & 29.16 & 155.1 & 107.60 & 88.3 & 50 \\
\hline Total Fosfat & $\mathrm{mg} / \mathrm{L}$ & 0.32 & 0.06 & 0.074 & 0.49 & 0.21 & 0.32 & 0.2 & 1 \\
\hline NH3 & $\mathrm{mg} / \mathrm{L}$ & 0.035 & 0.05 & 0.03 & 0.03 & 0.03 & 0.27 & 0.1 & 0 \\
\hline $\begin{array}{l}\text { Fecal } \\
\text { Coliform } \\
\text { Total }\end{array}$ & $\mathrm{Jml} / 100 \mathrm{ml}$ & 90000 & 90000 & 35000 & 28000 & 270 & 28000 & 45211.7 & 2000 \\
\hline Coliform & $\mathrm{Jml} / 100 \mathrm{ml}$ & 14000 & 22000 & 12000 & 3300 & 1500 & 10000 & 10466.7 & 10000 \\
\hline
\end{tabular}

L21 - L26 = berturut-turut lokasi titik sampling dari hilir ke hulu loloan sisi Selatan Pura Petitenget

*) = nilai rerata bulan April, Mei dan Juni

$\mathrm{BM}$ III = Baku Mutu air golongan III PerGub Bali No 16 Tahun 2016

$\square \quad$ = Warna hijau (<BM III), warna Kuning(mendekati BM III), warna merah(>BM III)

Pada Tabel 5,dapat dilihat bahwa terdapat beberapa parameter pencemar yang melampaui batas Baku Mutu Air Golongan III yang dipersyaratkan dalam PerGub Bali No.16 Tahun 2016. Parameter pencemar yang melebihi baku mutu salah satunya adalah Total Dissolved Solid (TDS) yang teridentifikasi pada sampel L21 yang terdapat pada hilir loloan sisi Selatan Pura Petitenget. Tingginya konsentrasi TDS pada sampel air loloan di hilir merupakan imbas oleh adanya pembuangan air limbah baik domestik maupun industri ke dalam loloan yang kemudian terakumulasi pada hilir loloan. Sumber pencemar TDS umumnya berasal dari zat kimia yang digunakan untuk pemrosesan pada industri dan air limbah domestik.

Parameter lainnya yang berpotensi memunculkan masalah pencemaran yang lebih besar adalah $\mathrm{pH}, \mathrm{BOD}, \mathrm{COD}, \mathrm{NH}_{3}$, fecal dan coliform yang memiliki konsentrasi diatas baku mutu. Tingginya BOD dan COD mengindikasikan tingginya zat organik yang terlarut dalam air loloan baik biodegradable maupun non-biodegradable. Tingginya zat organic dalam air loloan dapat menjadi masalah serius karena semakin tinggi zat organic maka semakin banyak mikroorganisme yang akan tumbuh dan berkembang biak yang menjadikan zat organic sebagai sumber makanan. Zat organic juga dapat menyebabkan pencemaran yang berkelanjutan karena kemampuan terdispersi dan terakumulasi yang cepat.

Selain itu, parameter ammonia $\left(\mathrm{NH}_{3}\right)$ yang umumnya berasal dari air seni makhluk hidup juga teridentifikasi melebihi baku mutu. Ammonia merupakan masalah yang serius karena ammonia memiliki bentuk lain yang sangat berbahaya jika masuk ke dalam tubuh manusia. $\mathrm{NH}_{3}$ ketika teroksidasi dapat menjadi $\mathrm{NO}_{2}$ dan $\mathrm{NO}_{3}$ selain itu dapat juga menjadi senyawa THM yang sama-sama merupakan senyawa karsinogenik. Sementara parameter fecal dan coliform menunjukan jumlah bakteri yang teridentifikasi pada air loloan. Fecal merupakan parameter jumlah bakteri pathogen yang dapat menimbulkan penyakit dan coliform merupakan parameter jumlah bakteri yang berpotensi menjadi agen pembawa penyakit. 
B. Status Loloan sisi Selatan Pura Petitenget

Tabel 6. Penentuan status/kriteria kualitas air loloan sisi Selatan Pura Petitenget Kerobokan Badung.

\begin{tabular}{|c|c|c|c|c|c|c|}
\hline \multirow[t]{2}{*}{ No } & \multirow[t]{2}{*}{ Parameter } & \multirow[t]{2}{*}{ Satuan } & \multirow[t]{2}{*}{ BM III } & \multicolumn{3}{|c|}{ Hasil Perhitungan } \\
\hline & & & & Maksimum & Minimum & Rerata \\
\hline A & Fisika & & & & & \\
\hline 1 & Suhu & $\mathrm{oC}$ & 28.5 & 0 & 0 & 0 \\
\hline 2 & TDS & $\mathrm{mg} / \mathrm{L}$ & 1000 & -1 & 0 & 0 \\
\hline 3 & TSS & $\mathrm{mg} / \mathrm{L}$ & 400 & 0 & 0 & 0 \\
\hline B & Kimia & & & & & \\
\hline 1 & $\mathrm{pH}$ & & & -2 & -2 & -6 \\
\hline 2 & NH3-N & $\mathrm{mg} / \mathrm{L}$ & 0 & -2 & -2 & -6 \\
\hline 3 & Phospat & $\mathrm{mg} / \mathrm{L}$ & 1 & 0 & 0 & 0 \\
\hline 4 & BOD & $\mathrm{mg} / \mathrm{L}$ & 6 & -2 & -2 & -6 \\
\hline 5 & COD & $\mathrm{mg} / \mathrm{L}$ & 50 & -2 & 0 & -6 \\
\hline $\mathrm{C}$ & Biologi & & & & & \\
\hline 1 & Fecal coli & $\mathrm{jml} / 100 \mathrm{~m}$ & 2000 & -3 & 0 & -9 \\
\hline 2 & Total Coli & $\mathrm{jml} / 100 \mathrm{~m}$ & 10000 & -3 & 0 & -9 \\
\hline & & & & -12 & -6 & -42 \\
\hline & & & & & & -60 \\
\hline
\end{tabular}

Kelas D, tercemar berat( $>-31)$

BM III = Baku Mutu air golongan III PerGub Bali No 16 Tahun 2016

\subsection{Loloan di Restorant Kudeta Kerobokan Badung (Loloan 3)}

A. Kualitas dan Status Mutu Air aktivitas domestic. Padatnya Loloan di Restorant Kudeta pembangunan terutama akomodasi Kerobokan Badung wisata disepanjang sungai memberi Pada loloan ini ditentukan 4 titik pengaruh pada kondisi fisik dan kualitas pengambilan sampel yang disesuiakan pencemaran air sungai tersebut yang dengan kondisi dan panjang sungai bermuara di kawasan Pantai Petitenget. dilokasi penelitian. Loloan ini berupa Berikut ditunjukan hasil pemeriksaan sungai kecil yang berfungsi sebagai dan analisis sampel air di titik drainase, namun sekarang menjadi pengambilan sampel di lokasi tersebut. tempat pengaliran limbah dari berbagai

Tabel 7. Hasil Pengukuran kualitas sampel air Loloan Sisi Utara Oberoi Kerobokan Bulan April - Juni 2018

\begin{tabular}{lrrrrrrr}
\hline Parameter & Satuan & L31* & L32* & L33* & L34* & rerata & $\begin{array}{c}\text { BM } \\
\text { III }\end{array}$ \\
\hline Suhu & OC & 30 & 29.3 & 29.8 & 28.3 & 29.3 & 28.5 \\
TDS & $\mathrm{Mg} / \mathrm{L}$ & 2864 & 2615.3 & 1399.1 & 1181.4 & 2015.0 & 1000 \\
TSS & $\mathrm{Mg} / \mathrm{L}$ & 32.5 & 46.2 & 109.1 & 44.0 & 57.9 & 400 \\
pH & - & 3.65 & 3.7 & 3.6 & 3.5 & 3.6 & 6 \\
BOD & $\mathrm{Mg} / \mathrm{L}$ & 16.55 & 34.2 & 46.5 & 26.6 & 31.0 & 6 \\
COD & $\mathrm{Mg} / \mathrm{L}$ & 92.9 & 138.2 & 127.0 & 126.5 & 121.2 & 50
\end{tabular}




\begin{tabular}{lrrrrrrr}
\hline Parameter & Satuan & \multicolumn{1}{c}{ L31* } & \multicolumn{1}{c}{ L32* } & L33* & L34* & rerata & \multicolumn{2}{c}{ BM } \\
\hline Total P & $\mathrm{Mg} / \mathrm{L}$ & 1.0795 & 1.3 & 4.7 & 1.8 & 2.2 & 1 \\
$\mathrm{NH} 3$ & $\mathrm{Mg} / \mathrm{L}$ & 0.079 & 0.1 & 0.1 & 0.1 & 0.1 & 0 \\
fecal & $\mathrm{Jml} / 100 \mathrm{ml}$ & 1705 & 5393 & 4921.0 & 1750.0 & 3442.3 & 2000 \\
Coliform & $\mathrm{Jml} / 100 \mathrm{ml}$ & 11550 & 11883.3 & 9494.4 & 13198.1 & 11531.5 & 10000 \\
\hline
\end{tabular}

Keterangan

L31 - L34 = berturut-turut lokasi titik sampling dari hilir ke hulu loloan sisi Utara Oberoi Kerobokan

*) = nilai rerata bulan April, Mei dan Juni

BM III = Baku Mutu air golongan III PerGub Bali No 16 Tahun 2016

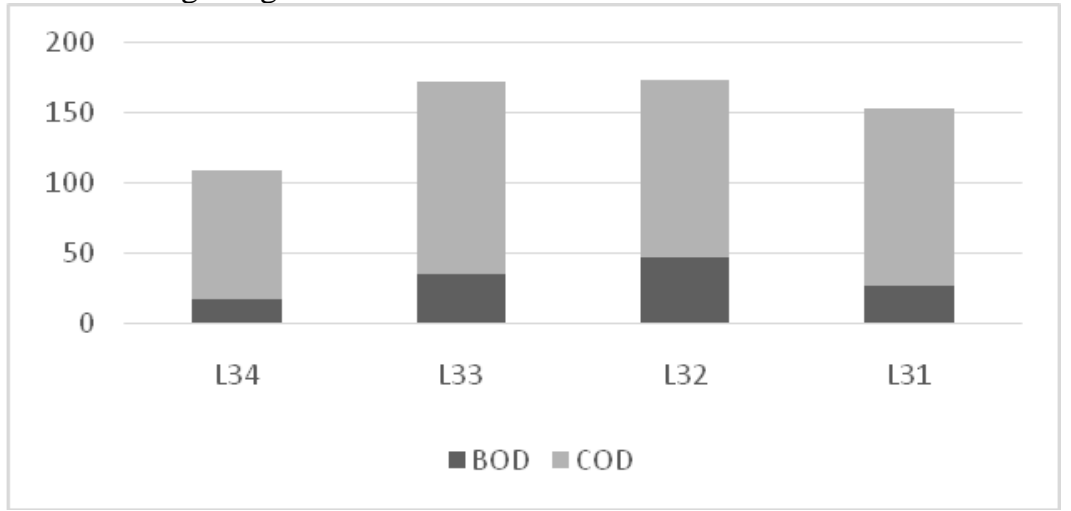

Gambar 3.

Karakter Beban oksidasi (BOD dan COD) Loloan Sisi Utara Oberoi Kerobokan Badung.

Keterangan

L31 - L34 = berturut-turut lokasi titik sampling dari hilir ke hulu loloan sisi Utara Oberoi Kerobokan BM III = Baku Mutu air golongan III PerGub Bali No 16 Tahun 2016

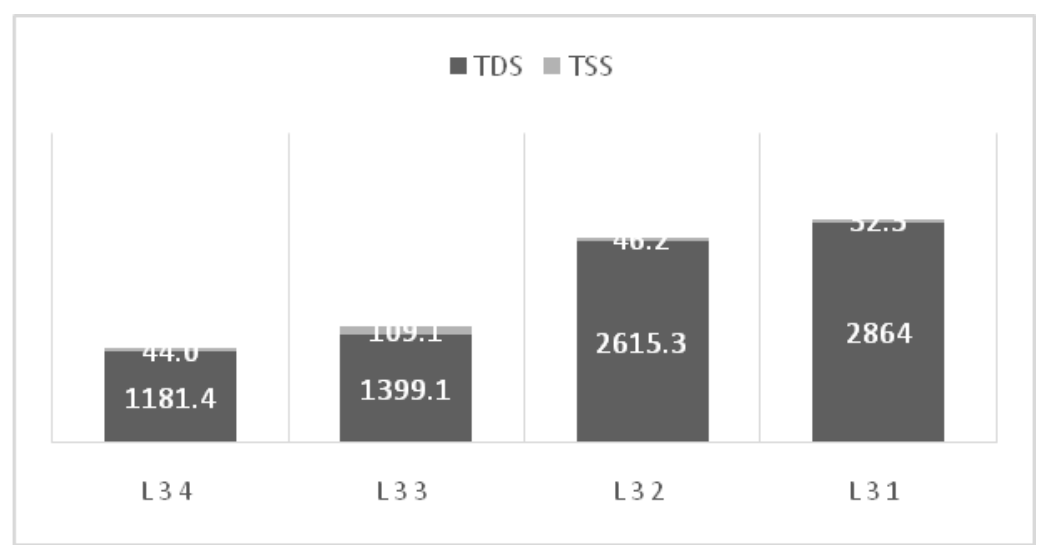

Gambar 4.

Karakter Beban TDS dan TSS Loloan Sisi Utara Oberoi Kerobokan Badung. Keterangan

L31 - L34 = berturut-turut lokasi titik sampling dari hilir ke hulu loloan sisi Utara Oberoi Kerobokan BM III = Baku Mutu air golongan III PerGub Bali No 16 Tahun 2016 
Tabel 8. Profil kualitas sampel air Loloan Sisi Utara Oberoi Kerobokan Bulan April

\begin{tabular}{|c|c|c|c|c|c|c|c|}
\hline Parameter & Satuan & L31 & L32 & L33 & L34 & rerata & BM III \\
\hline Suhu & OC & 30 & 29.3 & 29.8 & 28.3 & 29.3 & 28.5 \\
\hline TDS & $\mathrm{Mg} / \mathrm{L}$ & 2864 & 2615.3 & 1399.1 & 1181.4 & 2015.0 & 1000 \\
\hline TSS & $\mathrm{Mg} / \mathrm{L}$ & 32.5 & 46.2 & 109.1 & 44.0 & 57.9 & 400 \\
\hline $\mathrm{pH}$ & & 3.65 & 3.7 & 3.6 & 3.5 & 3.6 & 6 \\
\hline BOD & $\mathrm{Mg} / \mathrm{L}$ & 16.55 & 34.2 & 46.5 & 26.6 & 31.0 & 6 \\
\hline COD & $\mathrm{Mg} / \mathrm{L}$ & 92.9 & 138.2 & 127.0 & 126.5 & 121.2 & 50 \\
\hline Total P & $\mathrm{Mg} / \mathrm{L}$ & 1.08 & 1.3 & 4.7 & 1.8 & 2.2 & 1 \\
\hline $\mathrm{NH} 3$ & $\mathrm{Mg} / \mathrm{L}$ & 0.079 & 0.1 & 0.1 & 0.1 & 0.1 & 0 \\
\hline fecal & $\mathrm{Jml} / 100 \mathrm{ml}$ & 1705 & 5393 & 4921.0 & 1750.0 & 3442.3 & 2000 \\
\hline coliform & $\mathrm{Jml} / 100 \mathrm{ml}$ & 11550 & 11883.3 & 9494.4 & 13198.1 & 11531.5 & 10000 \\
\hline
\end{tabular}

L31 - L34 = berturut-turut lokasi titik sampling dari hilir ke hulu loloan sisi Utara Oberoi Kerobokan

*) = nilai rerata bulan April, Mei dan Juni

BM III = Baku Mutu air golongan III PerGub Bali No 16 Tahun 2016

$\square \square$ = Warna hijau (<BM III), warna Kuning(mendekati BM III), warna merah(>BM III)

Pada Tabel 8,dapat dilihat bahwa hampir semua parameter pencemar yang teridentifikasi pada air loloan sisi utara Oberoi melampaui batas Baku Mutu Air Golongan III yang dipersyaratkan dalam PerGub Bali No.16 Tahun 2016. Salah satu parameter baru yang melebihi baku mutu pada air sampel ini adalah Total
Phosphate. Umumnya tingginya kadar fosfat diakibatkan oleh sisa residu pupuk dan makanan yang masuk ke badan air. Dapat dikatakan bahwa loloan sisi utara Oberoi tercemar berat. Penilaian hasil pengukuran parameter kualitas air loloan sisi utara Oberoi dapat dilihat pada Tabel 9.

B. Status Loloan sisi Utara Oberoi Kerobokan

Tabel 9. Penentuan status/kriteria kualitas air loloan sisi Utara Oberoi Kerobokan Badung.

\begin{tabular}{|c|c|c|c|c|c|c|c|}
\hline \multirow{2}{*}{\multicolumn{2}{|c|}{ No }} & \multirow[t]{2}{*}{ Parameter } & \multirow[t]{2}{*}{ Satuan } & \multirow[t]{2}{*}{ BM III } & \multicolumn{3}{|c|}{ Hasil Perhitungan } \\
\hline & & & & & Maksimum & Minimum & Rerata \\
\hline \multirow[t]{4}{*}{ A } & & Fisika & & & & & \\
\hline & 1 & Suhu & $\mathrm{oC}$ & 28.5 & 0 & 0 & 0 \\
\hline & 2 & TDS & $\mathrm{mg} / \mathrm{L}$ & 1000 & -1 & -1 & -2 \\
\hline & 3 & TSS & $\mathrm{mg} / \mathrm{L}$ & 400 & 0 & 0 & 0 \\
\hline \multirow[t]{6}{*}{ B } & & Kimia & & & & & \\
\hline & 1 & $\mathrm{pH}$ & & & -2 & -2 & -6 \\
\hline & 2 & $\mathrm{NH} 3-\mathrm{N}$ & $\mathrm{mg} / \mathrm{L}$ & 0 & -2 & -2 & -6 \\
\hline & 3 & Phospat & $\mathrm{mg} / \mathrm{L}$ & 1 & -2 & -2 & -2 \\
\hline & 4 & BOD & $\mathrm{mg} / \mathrm{L}$ & 6 & -2 & -2 & -6 \\
\hline & 5 & COD & $\mathrm{mg} / \mathrm{L}$ & 50 & -2 & -2 & -6 \\
\hline \multirow[t]{5}{*}{$\mathrm{C}$} & & Biologi & & & & & \\
\hline & 1 & Fecal coli & $\mathrm{jml} / 100 \mathrm{~m}$ & 2000 & -3 & 0 & -9 \\
\hline & 2 & Total Coli & $\mathrm{jml} / 100 \mathrm{~m}$ & 10000 & -3 & 0 & -9 \\
\hline & & & & & -14 & -11 & -46 \\
\hline & & & & & & & -71 \\
\hline
\end{tabular}

Kelas D, tercemar berat(>-31)

BM III = Baku Mutu air golongan III PerGub Bali No 16 Tahun 2016 
3.4 Loloan Sisi Selatan Resort Oberoi Kerobokan Badung (Loloan 4)

A. Kualitas dan Status Mutu Air Loloan sisi Selatan Resort Oberoi Kerobokan Badung

Pada loloan ini ditentukan 4 titik pengambilan sampel yang disesuiakan dengan kondisi dan panjang sungai dilokasi penelitian. Loloan ini berupa sungai kecil yang berfungsi sebagai drainase, namun sekarang menjadi tempat pengaliran limbah dari berbagai aktivitas domestic. Padatnya pembangunan terutama akomodasi wisata disepanjang sungai memberi pengaruh pada kondisi fisik dan kualitas pencemaran air sungai tersebut yang bermuara di kawasan Pantai Petitenget. Berikut ditunjukan hasil pemeriksaan dan analisis sampel air di titik pengambilan sampel di lokasi tersebut.

Tabel 10. Hasil Pengukuran kualitas sampel air Loloan Sisi Selatan Oberoi Kerobokan Bulan April - Juni 2018

\begin{tabular}{lllllll}
\hline Parameter & Satuan & L41* & L42* & L43* & Rerata & BM III \\
\hline Suhu & OC & 29 & 29.7 & 28.33 & 29.0 & 28.5 \\
TDS & $\mathrm{Mg} / \mathrm{L}$ & 372.5 & 604.5 & 445.33 & 474.1 & 1000 \\
TSS & $\mathrm{Mg} / \mathrm{L}$ & 32 & 26.3 & 29.00 & 29.1 & 400 \\
$\mathrm{pH}$ & - & 3.75 & 3.7 & 3.83 & 3.8 & 6 \\
$\mathrm{BOD}$ & $\mathrm{Mg} / \mathrm{L}$ & 26.65 & 24.1 & 33.90 & 28.2 & 6 \\
$\mathrm{COD}$ & $\mathrm{Mg} / \mathrm{L}$ & 83.14 & 108.7 & 73.72 & 88.5 & 50 \\
Total P & $\mathrm{Mg} / \mathrm{L}$ & 0.323 & 0.3 & 0.28 & 0.3 & 1 \\
$\mathrm{NH} 3$ & $\mathrm{Mg} / \mathrm{L}$ & 0.0815 & 0.1 & 0.08 & 0.1 & 0 \\
fecal & $\mathrm{Jml} / 100 \mathrm{ml}$ & 2300 & 2866.7 & 1766.67 & 2311.1 & 2000 \\
Coliform & $\mathrm{Jml} / 100 \mathrm{ml}$ & 2200 & 2700 & 5633.33 & 3511.1 & 10000 \\
\hline
\end{tabular}

Keterangan

L41 - L43 = berturut-turut lokasi titik sampling dari hilir ke hulu loloan sisi Selatan Oberoi Kerobokan

*) = nilai rerata bulan April, Mei dan Juni

BM III = Baku Mutu air golongan III PerGub Bali No 16 Tahun 2016

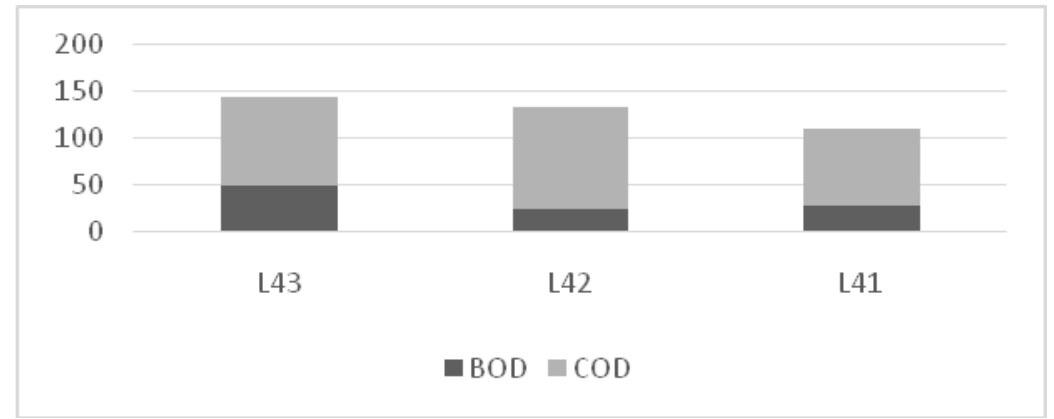

Gambar 5.

Karakter Beban oksidasi (BOD dan COD) Loloan Sisi Selatan Oberoi Kerobokan Badung.

Keterangan

L41 - L43 = berturut-turut lokasi titik sampling dari hilir ke hulu loloan sisi Selatan Oberoi Kerobokan

BM III = Baku Mutu air golongan III PerGub Bali No 16 Tahun 2016

Tabel 11. Profil kualitas sampel air Loloan Sisi Selatan Oberoi Kerobokan Bulan April - Juni 2018 


\begin{tabular}{lrrrrrr}
\hline \multicolumn{1}{c}{ Parameter } & \multicolumn{1}{c}{ Satuan } & \multicolumn{1}{c}{ L41 } & \multicolumn{1}{c}{ L42 } & L43 & rerata & BM III \\
\hline Suhu & $0 \mathrm{C}$ & 29 & 29.7 & 29 & 29.2 & 28.5 \\
TDS & $\mathrm{Mg} / \mathrm{L}$ & 372.5 & 604.5 & 575 & 517.3 & 1000 \\
$\mathrm{TSS}$ & $\mathrm{Mg} / \mathrm{L}$ & 32 & 26.3 & 9 & 22.4 & 400 \\
$\mathrm{pH}$ & - & 3.75 & 3.7 & 3.4 & 3.6 & 6 \\
$\mathrm{BOD}$ & $\mathrm{Mg} / \mathrm{L}$ & 26.65 & 24.1 & 48.5 & 33.1 & 6 \\
$\mathrm{COD}$ & $\mathrm{Mg} / \mathrm{L}$ & 83.14 & 108.7 & 96.4 & 96.1 & 50 \\
Total P & $\mathrm{Mg} / \mathrm{L}$ & 0.32 & 0.3 & 0.23 & 0.3 & 1 \\
$\mathrm{NH3}$ & $\mathrm{Mg} / \mathrm{L}$ & 0.08 & 0.1 & 0.09 & 0.1 & 0 \\
fecal & $\mathrm{Jml} / 100 \mathrm{ml}$ & 2300 & 2866.7 & 4600 & 3255.6 & 2000 \\
Coliform & $\mathrm{Jml} / 100 \mathrm{ml}$ & 2200 & 2700 & 2600 & 2500.0 & 10000 \\
\hline L41-L43 &
\end{tabular}

L41 - L43 = berturut-turut lokasi titik sampling dari hilir ke hulu loloan sisi Selatan Oberoi Kerobokan

*) = nilai rerata bulan April, Mei dan Juni

BM III = Baku Mutu air golongan III PerGub Bali No 16 Tahun 2016

: Warna hijau (<BM III), warna Kuning(mendekati BM III), warna merah(>BM III)

Pada Tabel 11,dapat dilihat bahwa parameter pencemar yang teridentifikasi pada air loloan sisi selatan Oberoi seperti $\mathrm{pH}, \mathrm{BOD}, \mathrm{COD}, \mathrm{NH}_{3}$, fecal coliform melebihi batas Baku Mutu Air Golongan III yang dipersyaratkan dalam PerGub
Bali No.16 Tahun 2016. Dapat dikatakan bahwa loloan sisi utara Oberoi tercemar berat. Penilaian hasil pengukuran parameter kualitas air loloan sisi utara Oberoi dapat dilihat pada Tabel 12.

B. Status Loloan sisi Selatan Oberoi Kerobokan

Tabel 12. Penentuan status/kriteria kualitas air loloan sisi utara Oberoi Kerobokan Badung.

\begin{tabular}{|c|c|c|c|c|c|c|c|}
\hline \multirow[t]{2}{*}{ No } & & \multirow[t]{2}{*}{ Parameter } & \multirow[t]{2}{*}{ Satuan } & \multirow[t]{2}{*}{ BM III } & \multicolumn{3}{|c|}{ Hasil Perhitungan } \\
\hline & & & & & Maksimum & Minimum & Rerata \\
\hline \multirow[t]{4}{*}{ A } & & Fisika & & & & & \\
\hline & 1 & Suhu & $\mathrm{oC}$ & 28.5 & 0 & 0 & 0 \\
\hline & 2 & TDS & $\mathrm{mg} / \mathrm{L}$ & 1000 & 0 & 0 & 0 \\
\hline & 3 & TSS & $\mathrm{mg} / \mathrm{L}$ & 400 & 0 & 0 & 0 \\
\hline \multirow[t]{6}{*}{ B } & & Kimia & & & & & \\
\hline & 1 & $\mathrm{pH}$ & & & -2 & -2 & -6 \\
\hline & 2 & $\mathrm{NH} 3-\mathrm{N}$ & $\mathrm{mg} / \mathrm{L}$ & 0 & -2 & -2 & -6 \\
\hline & 3 & Phospat & $\mathrm{mg} / \mathrm{L}$ & 1 & 0 & 0 & 0 \\
\hline & 4 & BOD & $\mathrm{mg} / \mathrm{L}$ & 6 & -2 & -2 & -6 \\
\hline & 5 & COD & $\mathrm{mg} / \mathrm{L}$ & 50 & -2 & -2 & -6 \\
\hline \multirow[t]{5}{*}{$\mathrm{C}$} & & Biologi & & & & & \\
\hline & 1 & Fecal coli & $\mathrm{jml} / 100 \mathrm{~m}$ & 2000 & -3 & -3 & -9 \\
\hline & 2 & Total Coli & $\mathrm{jml} / 100 \mathrm{~m}$ & 10000 & 0 & 0 & 0 \\
\hline & & & & & -11 & -11 & -33 \\
\hline & & & & & & & -55 \\
\hline
\end{tabular}

Kelas D, tercemar berat $(>-31)$

BM III = Baku Mutu air golongan III PerGub Bali No 16 Tahun 2016 


\section{SIMPULAN DAN SARAN}

\subsection{Simpulan}

Hasil analisis dari data pengukuran laboratorium kondisi dan status kualitas sungai/loloan yang bermuara di Kawasan Pantai Petitenget Kerobokan Kabupaten Badung dapat disimpulkan sebagai berikut:

1. Air dari keempatloloan(sungai) yang bermuara di kawasan Pantai Petitenget telah mengalami pencemaran yang terindikasi dari indicator $\mathrm{pH}, \mathrm{BOD}, \mathrm{COD}$, ammonia, Coliform dan E. coli yang tidak memenuhi Baku Mutu kualitas air golongan III(PerGub Bali No 16 Tahun 2016). Keempat sungai berada dalam status atau kriteria tercemar berat.

2. Keempat sungai telah mengalami kerusakan atau perubahan struktur secara fisik fluktuasi debit yang sangat tinggi baik secara kuantitas maupun kualitas. Struktur dasar berlendir, berbau dan estetika perairan yang kumuh.

3. Indikasi penimbul dampak pencemaran adalah air limbah dari berbagai akomodasi wisata yang memadati area sepanjang sungai meliputi hotel, restorant, homestay, pusat niaga dan permukiman.

\subsection{Saran}

1. Menetapkan daya tampung beban pencemaran

2. Inventarisasi dan identifikasi sumber pencemaran dilakukan oleh Pemerintah Propinsi dan pemerintah daerah Kabupaten Badung

3. Penetapan persyaratan air limbah untuk aplikasi pada tanah. Setiap usaha atau kegiatan yang akan memanfaatkan air limbah ke tanah untuk aplikasi pada tanah harus memiliki izin tertulis dari Bupati/
Walikota. Perizinan tersebut diberikan atas dasar hasil kajian AMDAL (Analisis Mengenai Dampak Lingkungan).

4. Menetapkan persyaratan pembuangan air limbah ke air atau sumber air

5. Memantau kualitas air pada sumber air

\section{DAFTAR PUSTAKA}

Ari Esta Kadek, Suarya dan Suastuti, 2016."Penentuan Status Mutu Air Tukad Yeh Pohdengan Metode Storet." Jurnal Kimia 10(1): ISSN1907-9850.

Azwir. 2006. Analisa Pencemaran Air SungaiTapung Kiri oleh Limbah Industri Kelapa SawitPT. Peputra Masterindo di KabupatenTanggerang. Tesis. Universitas Dipenogoro,Semarang.

Badan Pusat Daerah Aliran Sungai (BPDAS) UndaAnyar, 2015. Data DAS Pekerisan, 2005.Denpasar.

Boyd, CA.1982. Water Quality in Warm Water Fish Pond. Craft Master Printers, Alabama

Blume, K.K., J.C. Macedo, A. Meneguzzi, L.B. Silva,D.M. Quevedo, and M.A.S. Rodrigues. 2010. "Water Quality Assessment of the Sinos River,Southern Brazil". Journal of Biology, 70. 1185-1193.

Effendi, H. 2003. Telaah Kualitas Bagi PengelolaanSumber Daya dan Lingkungan Perairan. Penerbit Kanisius Yogyakarta.

Elyazar, N., M. Mahendra, dan Wardi. 2007. Dampak aktivitas masyarakat terhadap tingkat pencemaran air laut 
di pantai Kuta Kabupaten Badung serta upaya pelestarian lingkungan. J. of Environmental Science Ecotrophic, 2(1):1-18.

Pemerintah Provinsi Bali. 2007. Peraturan GubernurBali Nomor 8 Tahun 2007 tentang Baku MutuLingkungan dan Kriteria Baku KerusakanLingkungan Hidup.
Prihartanto dan Budiman, E.B. 2007. SistemInformasi Pemantauan Dinamika sungai Siak.Alami, Vol. 12 Nomor 1 Tahun 2007 : 52-60.

Susila D, K. G, I. W. Sandi Adnyana, I. W. Budiarsa Suyasa, 2012. Studi Kualitas Air Sungai TelagaWaja Kabupaten Karangasem. Ecotrophic.Volume 7 Nomor 1 Tahun 2012. Hal 47-53 